\title{
Phenotypic and genotypic characterization of a new fish-virulent Vibrio vulnificus serovar that lacks potential to infect humans
}

Correspondence

Carmen Amaro

carmen.amaro@uv.es

Received 19 December 2006

Revised 1 February 2007

Accepted 8 February 2007

\author{
Belén Fouz, Francisco J. Roig and Carmen Amaro
} Department of Microbiology and Ecology, Faculty of Biology, University of Valencia, Dr. Moliner 50,
46100 Burjassot, Valencia, Spain

\section{INTRODUCTION}

Vibrio vulnificus is an aquatic bacterium from warm and tropical ecosystems that produces diseases in humans and aquatic animals (Tison et al., 1982; Oliver, 1989; Amaro \& Biosca, 1996). Human vibriosis occurs after eating contaminated seafood or exposing open wounds to seawater (Veenstra et al., 1992; Strom \& Paranjpye, 2000), and fish vibriosis after immersion in contaminated water or contact with diseased animals or carriers (Amaro et al., 1995; Marco-Noales et al., 2001; Valiente \& Amaro, 2006).

The species has been subdivided into three biotypes on the basis of differences in biochemical properties, such as indole production and cellobiose fermentation, as well as serological and genetic traits and host range (Tison et al., 1982; Bisharat et al., 1999, 2007). Biotypes 1 (BT1) and 3 (BT3) are considered human pathogens and biotype 2 (BT2) pathogens of aquatic animals (Tison et al., 1982; Song et al., 1990; Biosca et al., 1996, 1997; Bisharat et al., 1999; Fouz et al., 2002, 2006a; Fouz \& Amaro, 2003) in spite of the fact that several human cases of wound infection and sepsis due to BT2 have occurred worldwide

Abbreviations: BT, biotype; ECP, extracellular product; GR, growth rate; $\mathrm{Hb}$, haemoglobin; RAPD, random amplified polymorphic DNA; Ser, serovar; SS, sterile saline; UPGMA, unweighted pair group method with arithmetic means.
(Veenstra et al., 1992; Amaro \& Biosca, 1996; Dalsgaard et al., 1996). BT2 was first isolated in Japan in 1976 (Muroga et al., 1976) and was described in 1982 by Tison et al. (1982). The first cases in Europe were recorded in 1989 in Spanish eel farms (Biosca et al., 1991). Later, the disease spread to other countries such as Sweden, The Netherlands and Denmark (Høi et al., 1998; Dalsgaard et al., 1999), always affecting eels cultured in brackish water.

BT2 is heterogeneous and can be subdivided into different serovars (Martin \& Siebeling, 1991; Biosca et al., 1996, 1997; Høi et al., 1998; Fouz \& Amaro, 2003). The first described, serovar E (SerE) (equivalent to serovar O4 according to the serotyping system of Martin \& Siebeling, 1991), is clearly related to both highly virulent epizootics and human infections (Veenstra et al., 1992; Amaro \& Biosca, 1996; Dalsgaard et al., 1996). This serovar seems to be genetically homogeneous regardless of origin, either human or fish (Gutacker et al., 2003). The last serovar described, serovar A (SerA), emerged in Southern Europe in 2000 (Fouz \& Amaro, 2003), affecting eels cultured in fresh water that had been vaccinated against SerE (Fouz et al., 2001). SerA spread to the Danish eel farming industry in the summer of 2004, also affecting eels cultured in fresh water (Fouz et al., 2006a). Two additional serovars, $\mathrm{O} 3$ and $\mathrm{O} 3 / \mathrm{O} 4$ (SerO3 and $\mathrm{SerO} 3 / \mathrm{O} 4)$, were only isolated once from diseased eels as secondary pathogens in Denmark in the mid-1990s (Høi et al., 1998). They were 
avirulent for eels by waterborne infection (Fouz et al., 2001). For this reason, their inclusion in BT2 is controversial.

To gain insight into the virulence factors that are essential for eel pathogenicity, genomes of selected strains belonging to the different biotypes, both virulent and avirulent for eels, were compared by suppression subtractive hybridization (Lee et al., 2005). This study demonstrated that all virulent BT2 strains analysed, irrespective of the serovar, shared plasmid-borne genetic sequences that could be considered as virulence markers for fish (Amaro et al., 2006).

The aim of the present work was to study the new emergent SerA in depth and to compare it with SerE. To this end, SerA isolates from different geographical origins were serologically, biochemically and genetically characterized, using reference strains of BT1, BT2 and BT3. Plasmid profiling, ribotyping and random amplified polymorphic DNA (RAPD) fingerprinting were chosen from among the different techniques available for epidemiological analysis, because they have been used by other authors to study intraspecific differentiation of $V$. vulnificus (Aznar et al., 1993; Biosca et al., 1997; Arias et al., 1997, 1998; Høi et al., 1997; Gutacker et al., 2003). Finally, the virulence for eels and mice (as a model for pathogenic potential for humans) of SerA isolates was also evaluated.

\section{METHODS}

Bacterial strains and growth conditions. A total of 30 strains of $V$. vulnificus SerA of different origins, as well as control strains of BT1, BT2 SerE and BT3, were used for this study (Table 1). SerA strains were isolated as pure cultures of opaque colonies (capsulated) from the internal organs, jaw or external ulcers of diseased eels (Fouz \& Amaro, 2003; Fouz et al., 2006a). The isolates were identified by colony hybridization using a $V$. vulnificus-specific alkaline-phosphatase-labelled DNA probe (DNA Technology) directed against the haemolysin/cytolysin gene $h l y A$ (Wright et al., 1993) and by slideagglutination with specific anti-SerA serum (Fouz \& Amaro, 2003; Fouz et al., 2006a). Bacterial strains were routinely grown on Tryptic Soy Agar (Oxoid) or Tryptic Soy Broth (Oxoid) supplemented with $0.5 \%(\mathrm{w} / \mathrm{v}) \mathrm{NaCl}$ (TSA-1 or TSB-1) at $28{ }^{\circ} \mathrm{C}$ for $24 \mathrm{~h}$. The strains were maintained both as lyophilized stocks and as frozen stocks at $-80{ }^{\circ} \mathrm{C}$ in marine broth (Difco) plus $20 \%$ (v/v) glycerol.

Table 1. Origin, biotype, serovar, biochemical characteristics and plasmid profile of $V$. vulnificus strains

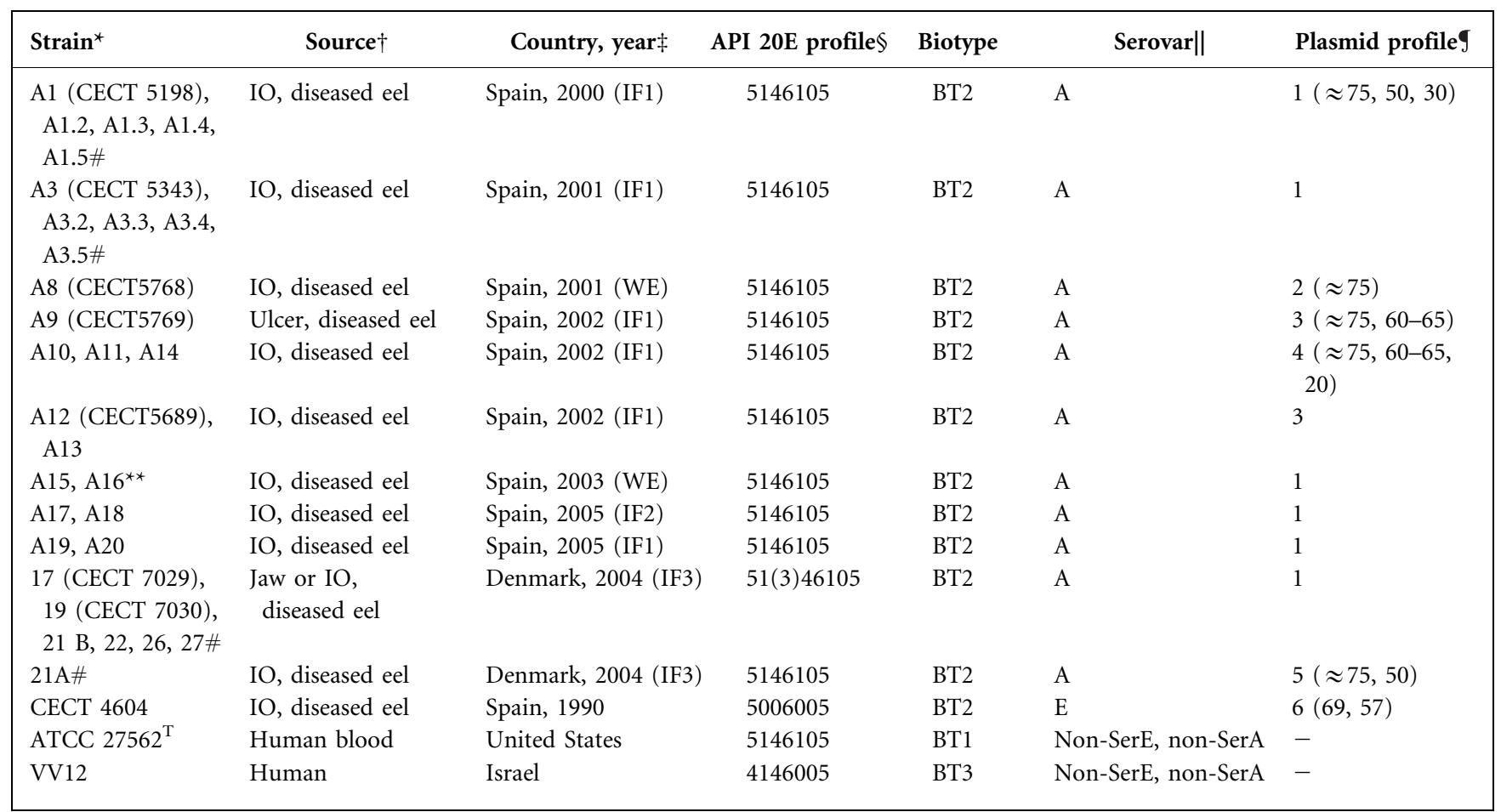

${ }^{\star}$ SerA isolates characterized in previous studies are marked with \#CECT, Spanish Type Culture Collection; ${ }^{* *}$ non-motile strains; ATCC, American Type Collection. T, type strain.

$\dagger \mathrm{IO}$, internal organ.

¥Isolates were recovered from diseased eels in outbreaks occurring in intensive farms (IF1, IF2 and IF3) or from diseased wild eels (WE).

§Identification according to the API database: 5146105, V. vulnificus (99.7\%); 5006005, V. vulnificus (54.4\%) or Burkholderia cepacia (45.3\%). IIBiotype 2 serovars were determined by slide-agglutination test with polyclonal antisera against serovars A and E.

I $1-5$, Profile of SerA strains on the basis of their plasmid content. 6, Profile of the SerE strain used as control. Molecular mass of plasmid bands is expressed in kilobases $(\mathrm{kb})$ in parentheses. - , without plasmids. 
Biochemical characterization. For biochemical characterization, all strains were seeded in API 20E strips (BioMerieux) and the profiles were compared with the API database (Apilab Plus, version 3.3.3; BioMerieux) (Amaro et al., 1992b; Sanjuán \& Amaro, 2004). Motility was assayed on TSA-1 motility plates containing $0.3 \%(\mathrm{w} / \mathrm{v})$ Bactoagar (Difco) (Gardel \& Mekalanos, 1996). Antibiotic susceptibility was checked by the disc diffusion method on Mueller-Hinton agar (Difco) supplemented with $1 \%(\mathrm{w} / \mathrm{v}) \mathrm{NaCl}$ (Amaro et al., 1992b) using tetracycline $(20 \mu \mathrm{g}$ per disc), flumequine $(30 \mu \mathrm{g}$ per disc), sulfamethoxazole/trimethoprim ( $25 \mu \mathrm{g}$ per disc) and oxolinic acid ( $2 \mu \mathrm{g}$ per disc) (Oxoid). Inhibition zones were read following incubation at $28{ }^{\circ} \mathrm{C}$ overnight.

Serological characterization. V. vulnificus isolates were serologically characterized by slide-agglutination with rabbit polyclonal antisera according to the previously described procedure (Amaro et al., 1992b). Antisera were prepared by intravenous injection of New Zealand rabbits with formalin-killed cells from strains of SerE (CECT 4604), SerA (CECT 5198), BT1 (ATCC 27562) and BT3 (VV12) according to the procedure described by Sorensen \& Larsen (1986). Antisera were also prepared against serovars O3 (strain 95-8-6) and O3/O4 (strain 95-8-161), occasionally involved in eel infections as secondary pathogens (Høi et al., 1998). Fresh and heated $\left(100{ }^{\circ} \mathrm{C}\right.$ for $2 \mathrm{~h}$ ) whole-cell suspensions containing $10^{8}$ c.f.u. $\mathrm{ml}^{-1}$ of each strain were used as antigens (Amaro et al., 1992b). A distinct and immediate agglutination was registered as positive. LPS extracts of all strains were prepared from both whole-cell lysates and extracellular products (ECPs) obtained by the cellophane technique (Liu, 1957) basically according to the method of Hitchcock \& Brown (1983). LPS samples from all strains were subjected to SDS-PAGE (Laemmli, 1970). LPS components fractionated by SDS-PAGE were analysed by both silver nitrate staining and immunostaining as previously described (Amaro et al., 1992a). In the latter case, LPS were transferred from the polyacrylamide gel to nitrocellulose sheets $(0.45 \mu \mathrm{m}$; Bio-Rad $)$ basically by the procedure of Towbin et al. (1979). Blotting was done at $200 \mathrm{~mA}$ for $2 \mathrm{~h}$ in Tris-glycine-methanol transfer buffer [25 mM Tris, $192 \mathrm{mM}$ glycine, $\mathrm{pH} 8.3$, and $20 \%$ (v/v) methanol]. LPS bands were visualized by immunostaining with serovar-specific polyclonal antibodies (dilutions $1: 200-1: 1000$ ) according to previously described procedures (Amaro et al., 1992a).

Plasmid analysis and PCR. Extraction of plasmid DNA was performed by the TENS method (Zhou et al., 1990) with slight modifications. Bacterial cells were grown in Luria Broth (Difco) for $6 \mathrm{~h}$ and frozen before starting the protocol, which included at least two steps of treatment with phenol. After DNA resuspension at room temperature, samples were subjected to eletrophoresis on $0.7 \%(\mathrm{w} / \mathrm{v})$ agarose gels (Roche, molecular grade) for $3 \mathrm{~h}$ at $50 \mathrm{~V}$. Molecular sizes of SerA plasmids were estimated using several reference plasmids from $V$. vulnificus SerE strain CECT 4999 (69 kb) and CECT $4604(69,57 \mathrm{~kb})$, Escherichia coli V517 (plasmids of 54.38, 7.30, 5.56, 5.14, 3.98, 3.08, 2.06, $2.71 \mathrm{~kb}$ ) and E. coli 39R861 (plasmids of 154, 66.2, 37.6, $7.4 \mathrm{~kb}$ ).

The presence of the identified BT2-specific plasmid-borne sequence 51 (seq51) (Lee et al., 2005; Amaro et al., 2006) in plasmid samples was tested using PCR (Lee et al., 2005). The accession number for this sequence seq51 in GenBank is AY691409 (Lee et al., 2005). The reaction mixture $(50 \mu \mathrm{l})$ contained $200 \mathrm{ng}$ DNA, each deoxynucleoside triphosphaate at a concentration of $0.2 \mu \mathrm{M}, 75 \mathrm{mM} \mathrm{MgCl}_{2}$, each primer at a concentration of $10 \mu \mathrm{M}$ (VF51, 5'-GGACAGATACAAGGGCAAATGG-3', and VR51, 5' -AGAGATGGAAGAAACAGGCG-3') and 2.5 U Taq polymerase (Amersham Biosciences) in PCR buffer (Amersham Biosciences). The reaction started with 5 min of denaturation at $94^{\circ} \mathrm{C}$, which was followed by 25 cycles of $30 \mathrm{~s}$ of denaturation at $94{ }^{\circ} \mathrm{C}, 1 \mathrm{~min}$ of annealing at $55-65^{\circ} \mathrm{C}$ and $1 \mathrm{~min}$ of extension at $72{ }^{\circ} \mathrm{C}$. An additional extension at $72{ }^{\circ} \mathrm{C}$ for $10 \mathrm{~min}$ completed the reaction. A negative control (no template DNA) and a positive control (purified DNA of the SerE strain CECT 4604) were included in each PCR batch. The amplified products were separated by electrophoresis on $1.8 \%(\mathrm{w} / \mathrm{v})$ agarose gels and were visualized by staining with ethidium bromide. Strain CECT 4604 of SerE was used as positive control.

Ribotyping. The SerA isolates were characterized by automated ribotyping with the Riboprinter (Qualicon). Ribotyping was performed under the conditions recommended by the manufacturer (Clermont et al., 2001) except that EcoRI was replaced by HindIII (Roche) (400 $\mathrm{U} \mathrm{Hl}^{-1}$ in standardized reagents in $1.5 \mathrm{ml}$ tubes). Each isolate was ribotyped twice.

RAPD-PCR analysis. Chromosomal DNA was extracted by the method outlined by Pitcher et al. (1989) and further purified by RNase and proteinase $\mathrm{K}$ treatments as described by Sambrook et al. (2001). RAPD analysis was performed using the universal primers M13 (5'GAAACAGCTATGACCATG-3') and T7 (5'-AATACGACTCACTATAGG-3'). PCR was conducted in a total volume of $50 \mu \mathrm{l}$ containing $1 \mu \mathrm{l}$ universal primer $(50 \mathrm{mM}), 0.5 \mu \mathrm{l}$ Taq DNA polymerase (Genotaq;

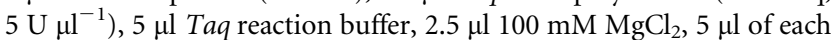
deoxynucleoside triphosphate $(10 \mathrm{mM}$ ) and $5 \mu$ template DNA (50 ng $\left.\mu^{-1}\right)$. Reaction mixtures were subjected to one cycle (MJR thermocyler) of $94{ }^{\circ} \mathrm{C}$ for $5 \mathrm{~min}$, followed by 45 cycles of $94{ }^{\circ} \mathrm{C}$ for $40 \mathrm{~s}, 36^{\circ} \mathrm{C}$ for $1 \mathrm{~min}$ and $72^{\circ} \mathrm{C}$ for $1 \mathrm{~min}$. This was followed by a cycle of $72{ }^{\circ} \mathrm{C}$ for $10 \mathrm{~min}$. The amplification products were electrophoresed at $100 \mathrm{~V}$ for 3 $\mathrm{h}$ on a $1.2 \%(\mathrm{w} / \mathrm{v})$ agarose (Low EEO, Pronadisa) gel in TBE buffer

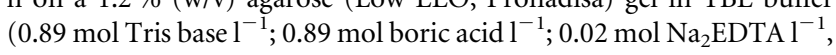
$\mathrm{pH}$ 8.3). Gels were stained with ethidium bromide and photographed under UV light. Gel images were recorded with a video camera (GelPrinter Plus, TDI) and stored as TIFF files. Digitized images were converted, normalized and analysed with the software package Gel Compar version 4.1 (Applied Maths). Similarity among band patterns was calculated with the Pearson product-moment correlation coefficient and dendrograms were constructed by the unweighted pair group method with arithmetic means (UPGMA). A band position tolerance of $1 \%$ was allowed to compensate for misalignments of homologous bands due to technical imperfections. The assay was done in duplicate.

Resistance to eel and human sera. The survival in fresh eel and human sera was assayed with stationary-phase bacteria in microtitre plates (Sanjuán \& Amaro, 2004). In each well, a volume of $20 \mu \mathrm{l}$ serum was mixed with $20 \mu$ l of a suspension of bacteria $\left(10^{4}-10^{5}\right.$ c.f.u. $\mathrm{ml}^{-1}$ ) in sterile saline solution [0.9\% (w/v) $\left.\mathrm{NaCl}, \mathrm{pH} 7, \mathrm{SS}\right]$. The assays were performed in triplicate and samples were obtained at 0,1 , 2 and $4 \mathrm{~h}$ incubation at $28{ }^{\circ} \mathrm{C}$ (eel serum assay) or $37^{\circ} \mathrm{C}$ (human serum assay). Viable counts were determined by drop plating on TSA1. The final growth rate (GR) was calculated for each strain as the log of the final count divided by the initial count and was coded as follows: $1(0<\mathrm{GR} \leqslant 1), 2(1<\mathrm{GR} \leqslant 2)$, or $3(3<\mathrm{GR})$.

Virulence assays. Virulence for eels was assayed using juvenile European elvers (mean weight of $10 \mathrm{~g}$ ). Fish were maintained in aquaria containing 91 water $[0.5 \%(\mathrm{w} / \mathrm{v})$ salinity $]$ at $25^{\circ} \mathrm{C}$. In order to study the pathogenic potential for humans, the virulence for BALB/c mice (mean weight $20 \mathrm{~g}$ ) was also assayed. Since the virulence of $V$. vulnificus increases greatly when haemoglobin $(\mathrm{Hb})$ is injected before bacterial infection (Amaro \& Biosca, 1996), groups of mice were also pretreated with $\mathrm{Hb}(1.5-2.15 \mu \mathrm{g} \mathrm{Fe}$ as $\mathrm{Hb}$ per g body weight; ironloaded mice) using the induced peritonitis model (Helms et al., 1984). Bacterial doses ranging from $10^{1}$ to $10^{8}$ c.f.u. per animal were intraperitoneally injected as previously described (Amaro et al., 1992a). Groups of six animals were used for each experiment and mortalities were recorded daily for 7 days. Mortalities were only considered to be caused by $V$. vulnificus if the inoculated bacterium was recovered as pure culture from internal organs. For identification, we used the slideagglutination test with the corresponding serum. Two groups of 
animals were challenged with SS and included as negative controls. For each $V$. vulnificus strain tested, the $\mathrm{LD}_{50}$ was calculated by the procedure of Reed \& Muench (1938).

\section{RESULTS}

\section{Biochemical characterization}

All SerA isolates gave the same API 20E profile as the type strain of the species, which belongs to BT1 (Table 1). This profile differed from the SerE profile in indole production, ornithine decarboxylation and acid production from Dmannitol, tests negative for SerE and positive for SerA. Moreover, SerA isolates differed from BT3 in ONPG activity and acid production from D-mannitol. According to the API database, this profile would correspond to $V$. vulnificus with a probability of $99.7 \%$. Most of the strains were motile, with the exception of isolates recovered from wild eels in 2003 (Table 1), which were unable to penetrate motility agar. All of them were also sensitive to all the antibiotics tested, as was the SerE isolate used as control in the susceptibility assays.

\section{Serological characterization}

All SerA isolates gave a strong positive reaction with the anti-SerA serum and a negative response with the antisera against the type strain (BT1), BT3 and SerE, regardless of the antigen used in the tests, fresh or heated whole-cell suspensions. SerA strains exhibited slight cross-reactions with $\mathrm{O} 3$ and $\mathrm{O} 3 / \mathrm{O} 4$ antisera when the agglutination tests were carried out with fresh whole cells, which disappeared when heated cells were used.

The LPS of isolates were further analysed by Western blotting with BT2 antisera. LPS of SerA isolates were visualized after immunostaining with anti-SerA serum (Fig. 1) but not after silver staining or after immunostaining with anti-SerE serum (data not shown). Conversely, LPS from the SerE isolate did not react with anti-SerA serum (Fig. 1). All SerA LPS samples, those obtained from both whole-cell lysates and ECPs, exhibited the same pattern, which presented a ladder-like structure typical of smooth LPS (Fig. 1). This band pattern differed from that shown by the SerE strain (Fig. 1). Thus, two highly immunogenic zones of middle and fast mobility were identified in the SerA-LPS band pattern, whereas only one zone of low mobility was identified in the SerE-LPS pattern. Finally, the fast-migrating band corresponding to the lipid A and core region of LPS from SerO3, SerO3/O4 and BT3 strains was stained with anti-SerA serum (Fig. 1). Similarly, the same moiety of LPS of SerA isolates was stained with anti-SerO3, anti-SerO3/O4 and anti-BT3 sera (data not shown).

\section{Plasmid analysis and PCR}

All SerA isolates harboured a large plasmid of approximately $75 \mathrm{~kb}$ (Fig. 2, Table 1). This plasmid was slightly

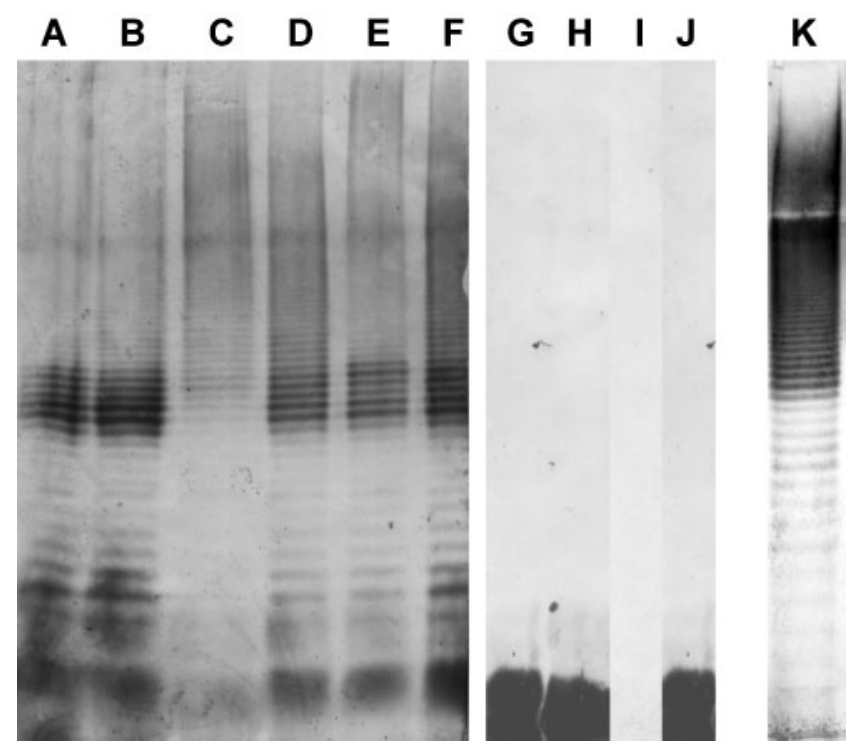

Fig. 1. LPS profiles of $V$. vulnificus SerA isolates $A 1$ (lane $A$ ), $A 8$ (B), A9 (C), A14 (D), A15 (E) and 17 (F), SerO3 isolate 95-8-6 (G), SerO3/O4 isolate 95-8-161 (H), SerE isolate CECT 4604 (I) and BT3 isolate VV12 (J) visualized by immunostaining with antiSerA serum diluted $1: 1000$. K, LPS profile of $V$. vulnificus SerE isolate CECT 4604 after immunostaining with its homologous antiserum diluted $1: 1000$.

larger than the high- $M_{\mathrm{r}}$ plasmid, around $69 \mathrm{~kb}$, found in the SerE strain (Fig. 2). Most SerA isolates had a second large plasmid of around 50-65 kb (Fig. 2, Table 1). A third smaller plasmid of around $20-30 \mathrm{~kb}$ was present in two of the five groups established on the basis of the plasmid profiling (Table 1). The majority of isolates (groups 1 and 4) harboured three plasmids, whereas only one strain, Spanish isolate A8 (group 2), carried one plasmid, the common high- $M_{\mathrm{r}}$ one. Groups 3 and 4, comprising Spanish isolates recovered from the same outbreak in 2002, harboured a second plasmid of approximately 60$65 \mathrm{~kb}$ (Table 1). The non-motile strains isolated from wild eels displayed the group 1 plasmid profile (Fig. 2, Table 1). Thus, similar plasmid profiles were observed in isolates from different geographical origins and also in isolates recovered from either wild or cultured eels (Table 1). No plasmids were visualized in BT1 and BT3 control strains (Table 1).

The BT2-specific plasmidic sequence seq51 was searched for in SerA strains using PCR with the specific primer pair derived from the sequence. In the PCR assays, all SerA strains were positive, giving the amplification product specific for seq51, a band of $344 \mathrm{bp}$ (data not shown).

\section{Ribotyping}

Since V. vulnificus biotypes and serovars are genotypically distinguishable by ribotyping (Aznar et al., 1993; Biosca 


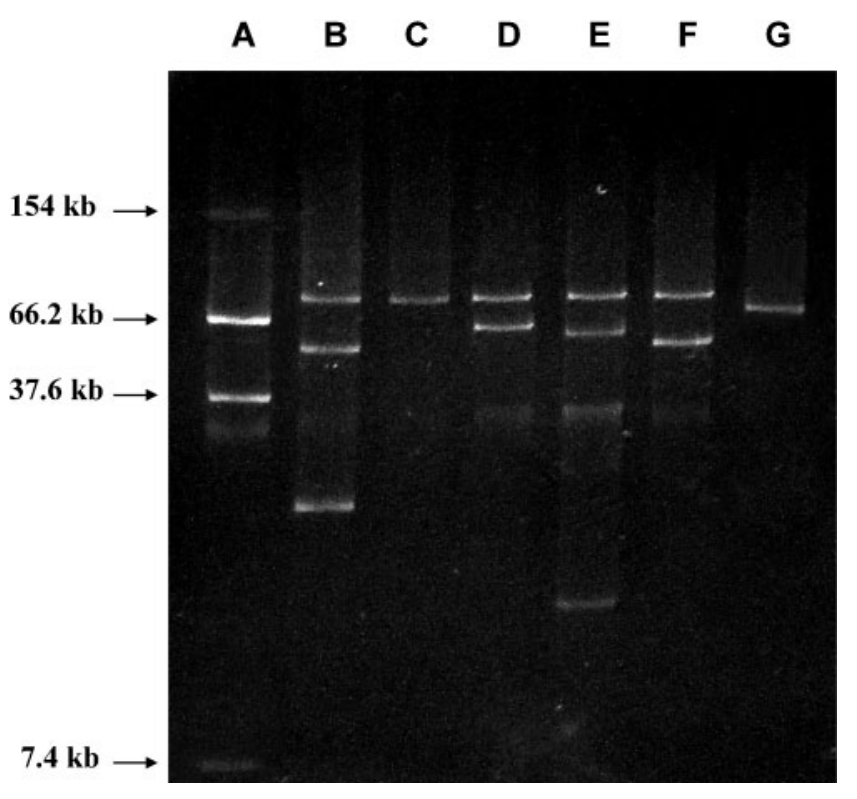

Fig. 2. Plasmid profiles of $E$. coli 39R861 (lane A) and selected $V$. vulnificus SerA (lane B, A1-group 1; C, A8-group 2; D, A9-group 3; E, A14-group 4; F, 21A-group 5) and SerE (G, CECT4999) strains. Plasmids were extracted following basically the method of Zhou et al. (1990).

et al., 1997; Arias et al., 1997, 1998), this technique was applied to all isolates to investigate the genetic homology of SerA isolates. We selected ribotyping with HindIII because it displays the separation of the resulting fragments very well. Ribotyping of all SerA strains using HindIII yielded a common pattern consisting of eight bands ranging from 1.2 to $7.5 \mathrm{~kb}$ (Fig. 3). This ribopattern was different from those displayed by the SerE and type strains (Fig. 3). In these two different ribotypes, eight bands in the same range of molecular masses were also observed (Fig. 3).

\section{Genetic relationships inferred by RAPD}

The RAPD-PCR technique, based on primers M13 and T7, was applied to SerA isolates with the aim of detecting strain- or serovar-specific DNA profiles. RAPD-PCR with primer M13 and T7 of SerA isolates rendered reproducible patterns consisting of six to ten bands ranging from 270 to $1125 \mathrm{bp}$ and from 341 to $1473 \mathrm{bp}$, respectively. Results obtained with both primers allowed the differentiation of the isolates at the intraspecific level and it was possible to distinguish individual strains within SerA. Fig. 4 shows the clusters defined at an $84 \%$ similarity level by RAPD patterns obtained with primer M13. All SerA strains grouped together (cluster 1) and could be clearly separated from the type strain of the species and the reference SerE strain. At an $86 \%$ similarity level, SerA strains were distributed in three subclusters, regardless of their geographical origin (Fig. 4).

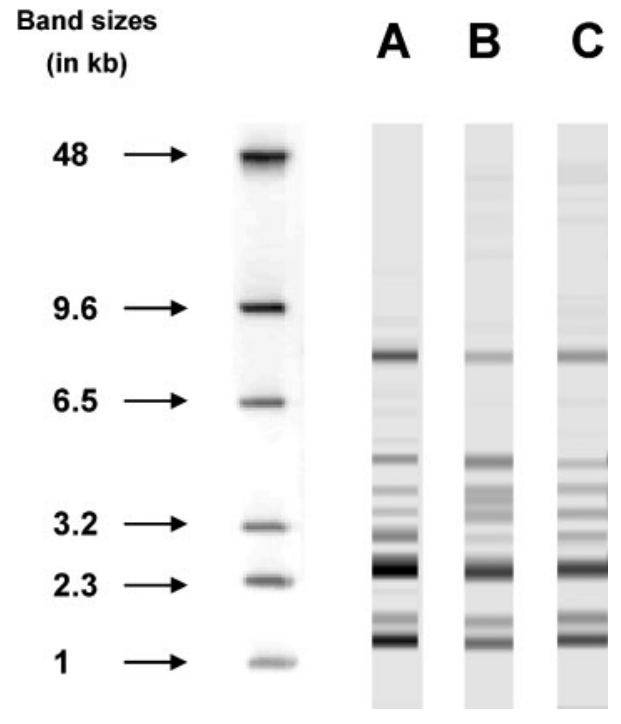

Fig. 3. Ribotypes obtained with Hindlll for representative $V$. vulnificus strains. Lanes: riboprinter molecular mass markers (values are given in kb on the left); A, SerA strain A1; B, SerE strain CECT 4604; C, BT1 strain ATCC 27562. Ribotyping was performed by automated ribotyping with the Riboprinter (Clermont et al., 2001).

A cluster analysis of RAPD profiles obtained with primer T7 revealed four groups of strains within SerA at an $84 \%$ similarity level and two strains remained ungrouped (data not shown). As with primer M13, SerE strain showed a clearly different pattern from those of SerA. However, the type strain grouped with SerA strains (data not shown). Therefore, based on RAPD-PCR patterns, SerA strains can clearly be separated from SerE strain using primers M13 or T7, and also from type strain of BT1 if primer M13 is used.

\section{Resistance to sera and virulence assays}

All SerA strains could survive and grow in fresh eel serum, and most of them gave bacterial yields similar to those of the control SerE strain (Table 2). However, SerA strains did not resist the bactericidal action of fresh human serum, with a large reduction ( $\geqslant 2 \log$ units) in the cell counts noticeable at the end of the experiments (Table 2).

As expected, all SerA isolates were virulent for eels after intraperitoneal injection, the majority of them with high $\mathrm{LD}_{50} \mathrm{~S}$ ranging from $3.0 \times 10^{1}$ to $6.2 \times 10^{2}$ c.f.u. per fish (Table 2). Moribund fish showed clinical signs of haemorrhagic septicaemia and $V$. vulnificus SerA was recovered from all of them in pure culture. The $\mathrm{LD}_{50}$ of the most virulent SerA strains was even lower than that of the SerE used as control (Table 2). However, none of the tested SerA strains were virulent for mice or iron-overloaded 


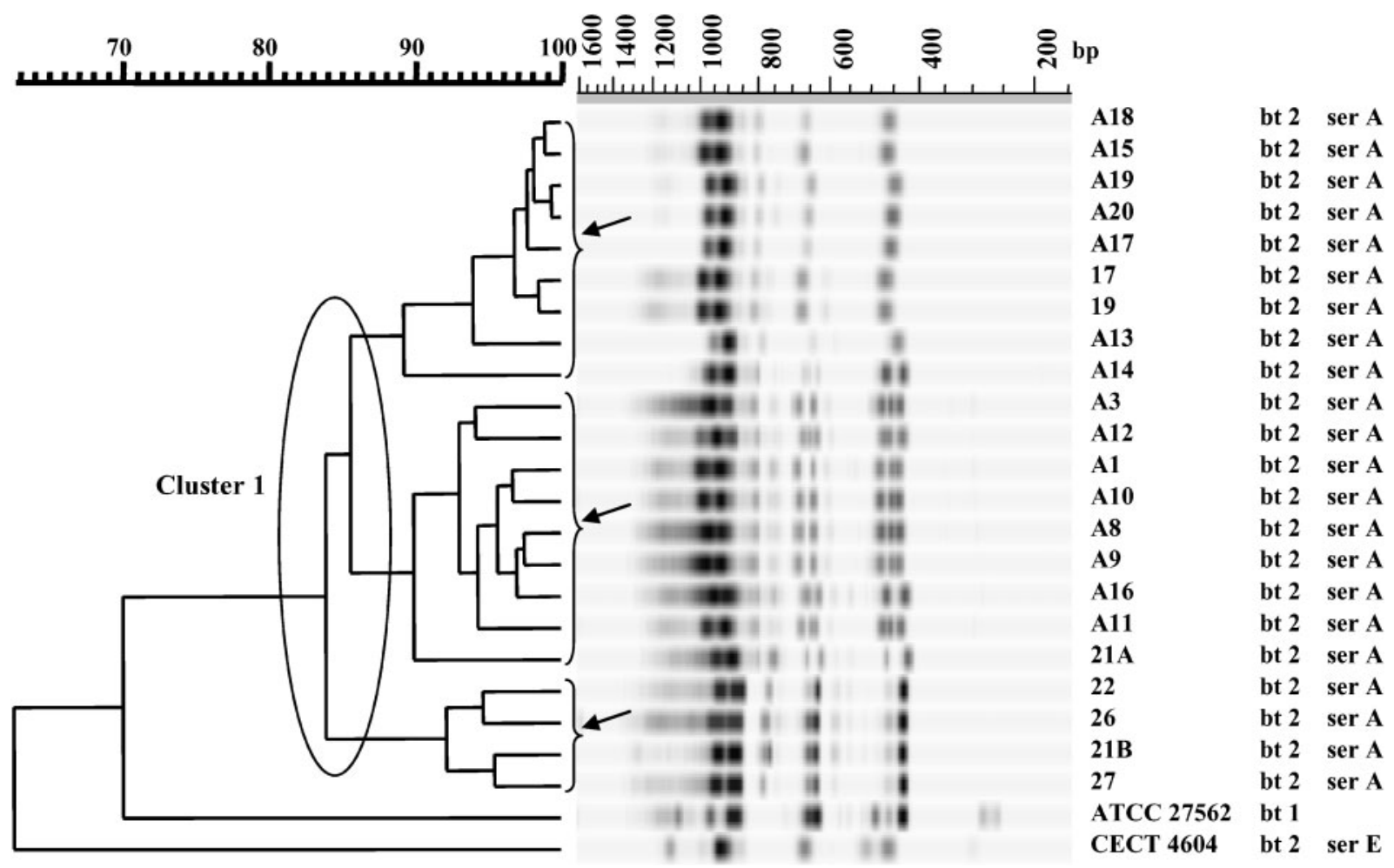

Fig. 4. Cluster analysis of the RAPD patterns obtained with universal primer $M 13$ of $V$. vulnificus strains performed with Pearson coefficient and UPGMA. The banding pattern corresponding to each type is shown on the right. Subclusters are indicated with arrows.

mice. In fact, $\mathrm{LD}_{50}$ s were higher than $10^{7}$ or $10^{5}$ c.f.u. per mouse for untreated or Hb-treated animals in all cases (Table 2). No significant reduction in $\mathrm{LD}_{50}$ was observed after iron treatment of mice, as occurred in SerE strain (Table 2).

\section{DISCUSSION}

SerA isolates were highly homogeneous as well as very sensitive to antibiotics, which is in accordance with the character of the SerA as an emergent pathogen. All strains

Table 2. Virulence for eels and mice, effect of iron treatment on susceptibility of mice to infection, and growth in eel and human sera of selected isolates

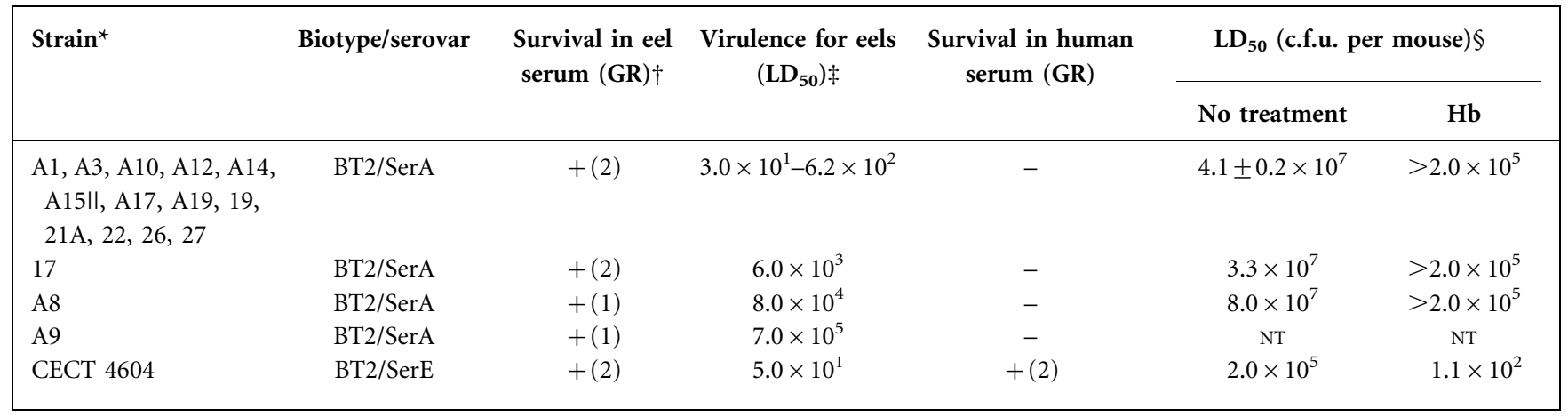

${ }^{\star}$ CECT, Spanish Type Culture Collection; Ilnon-motile strain.

$\dagger$ The final growth rate (GR) in serum was calculated for each strain as the log (final count/initial count) and was coded as $1(0<\mathrm{GR} \leqslant 1)$ or 2 $(1<\mathrm{GR} \leqslant 2)$.

$\ddagger \mathrm{LD}_{50}$ after intraperitoneal injection (c.f.u. per fish).

$\mathrm{LD}_{50}$ after intraperitoneal injection for mice without and with iron (as haemoglobin, Hb) treatment before infection (Helms et al., 1984). NT, Not tested. 
gave an identical API 20E profile to that of the type strain of the species and were correctly identified at species level. The profile differed from that of the SerE isolates in indole and ornithine decarboxylation tests, confirming the limited value of both assays as BT markers. The only exception was the motility characteristic, which was negative for two isolates from wild eels. The lack of motility has already been reported in other typically motile bacterial pathogens (Fouz et al., 2006b; Gardel \& Mekalanos, 1996), including V. vulnificus (Esteve et al., 2007). The use of vaccination against V. vulnificus at farms (Esteve-Gassent et al., 2004) could have favoured the emergence of these non-motile strains by selective pressure against flagellar antigens, similarly to what has occurred with other motile fish pathogens (Fouz et al., 2006b). The new non-motile variant could have been transmitted to wild eels from cultured eels, set free in natural environments for restocking purposes.

Serological assays by slide-agglutination tests suggested that the SerA isolates constituted an antigenically homogeneous group, distinguishable from SerE. This finding was confirmed after LPS extraction and analysis by immunoblotting. Thus, all SerA strains exhibited identical LPS with a ladder-like structure that differed from that found in the control SerE strain and from those previously published for BT1, BT2-SerE and BT3 strains (Amaro et al., 1992b; Biosca et al., 1996; Bisharat et al., 2007). In addition, no cross-reactions were detected between LPS from SerA and SerE strains, although some cross-reactions with antiSerO3, -SerO3/O4 and -BT3 sera that affected the lipid A and core region of SerA-LPS were detected. These results could partially explain the slight cross-reactions obtained in agglutination tests among serovars $\mathrm{A}, \mathrm{O} 3$ and $\mathrm{O} 3 / \mathrm{O} 4$ or those previously found in dot blot assays between SerA and BT3 (Bisharat et al., 2007). From these data, it has been concluded that the serological specificity of this new group would be based on the O-antigen of the LPS. This molecule could be a good candidate for the development of rapid methods to detect this emergent pathogen.

The presence of plasmids of high $M_{\mathrm{r}}$ in BT2 strains has previously been reported (Biosca et al., 1997; Høi et al., 1998; Lewin et al., 2000). In fact, three BT2-specific plasmidic sequences have been found by comparison of BT1 and BT2 genomes by subtractive hybridization (Lee et al., 2005). From these sequences, only one, seq51, was related to a putative open reading frame (orf51) (Lee et al., 2005). The authors concluded that the SerE plasmid of about $68 \mathrm{~kb}$, harbouring orf 51 , was related to eel virulence (Lee et al., 2005; Amaro et al., 2006). Results obtained in the present study are in accordance with the above hypothesis since all SerA strains (i) gave the expected product after PCR amplification with primers directed against orf51 and (ii) harboured one apparently common large plasmid, which could be involved in the eel virulence of this emergent serovar. However, the plasmid profiles lacked epidemiological value since they did not enable isolates to be grouped on the basis of geographical origin or source, as reported for SerE strains (Biosca et al., 1997). The molecular size of the common SerA plasmid was slightly higher than that of the common SerE plasmid, which suggests that the two plasmids are not identical. Studies are under way concerning the homology between the high- $M_{\mathrm{r}}$ plasmid harboured by SerA and SerE strains.

All SerA strains, irrespective of their geographical origin, presented identical or nearly identical ribopatterns after HindIII digestion, which would suggest their genetic proximity. This pattern was different from that shown by control strains of BT1 and SerE [ribopattern that corresponded to the predominant one of this serovar (Arias et al., 1997, 1998; Biosca et al., 1997)]. The genetic proximity among SerA isolates was also observed by RAPD-PCR. In fact, SerA strains clustered together, separately from the SerE strain, on the basis of RAPD analysis. Of the two primers used, M13 corresponded optimally with the results obtained by ribotyping, as previously reported by other authors (Aznar et al., 1993; Arias et al., 1998). The homogeneity found in the ribopatterns and RAPD profiles with M13 among strains of SerA correlates with the serological results and suggests that all SerA isolates belong to the same clonal group and are different from SerE isolates. This heterogeneity had previously been found among eel isolates by other authors using different serovars and approaches, such as sequence typing, multilocus enzyme electrophoresis and RAPD (Gutacker et al., 2003). Our data and those of these authors strongly suggest the existence of distinct genetic groups associated with disease in eels.

Finally, virulence assays revealed that all SerA isolates, including the non-motile ones, were highly virulent for eels but avirulent for mice, even after pretreatment with iron. These results correlated with those of resistance to the bactericidal activity of eel and human sera. Since resistance to the bactericidal action of serum is clearly related to the infective potential of this species (Amaro et al., 1997), it is reasonable to speculate that SerA is unable to produce disease in humans. Furthermore, the tested SerA strains developed opaque colonies on conventional media, suggesting that the lack of virulence for mice or the inability to withstand human serum could not be explained by the absence of capsule as occurs in BT1 and BT2 SerE strains (Amaro et al., 1994; Amaro \& Biosca, 1996; Oliver, 1989; Strom \& Paranjpye, 2000).

\section{Conclusion}

$V$. vulnificus SerA, a genetically distinct group within the species $V$. vulnificus, is highly virulent for eels but lacks potential to infect humans. This group could have evolved from another non-pathogenic one by horizontal acquisition of a fish-virulence plasmid. In order to elucidate this hypothesis, further studies on the genetic basis of the virulence potential of SerA are currently in progress. 


\section{ACKNOWLEDGEMENTS}

The technical assistance of Amparo Llorens and the help of Javier Pascual in RAPD analysis are highly appreciated. This work has been financed by projects AGL2002-01291 and AGL2005-04688 from the Spanish Ministry for Education and Science (SMES) and GV2005-296 from Consellería de Empresa, Universidad y Ciencia from the Government of Valencia. B. F. thanks SMES for her research contract 'Ramón y Cajal'. The authors thank the Generalitat Valenciana facilities for supplying eels. Some experiments were performed in the Experimental Aquaculture Plant of the University of Valencia. English text revised by F. Barraclough.

\section{REFERENCES}

Amaro, C. \& Biosca, E. G. (1996). Vibrio vulnificus biotype 2, pathogenic for eels, is also an opportunistic pathogen for humans. Appl Environ Microbiol 62, 1454-1457.

Amaro, C., Biosca, E. G., Fouz, B. \& Garay, E. (1992a). Electrophoretic analysis of heterogeneous lipopolysaccharides from various strains of Vibrio vulnificus biotypes 1 and 2 by silver staining and immunoblotting. Curr Microbiol 25, 99-104.

Amaro, C., Biosca, E. G., Esteve, C., Fouz, B. \& Toranzo, A. E. (1992b). Comparative study of phenotypic and virulence properties in $V$. vulnificus biotype 1 and 2 obtained from a European eel farm experiencing mortalities. Dis Aquat Organ 13, 29-35.

Amaro, C., Biosca, E. G., Fouz, B., Toranzo, A. E. \& Garay, E. (1994). Role of iron, capsule and toxins in the pathogenicity of Vibrio vulnificus biotype 2 for mice. Infect Immun 62, 759-763.

Amaro, C., Biosca, E. G., Fouz, B., Alcaide, E. \& Esteve, C. (1995). Evidence that water transmits Vibrio vulnificus biotype 2 infections to eels. Appl Environ Microbiol 61, 1133-1137.

Amaro, C., Fouz, B., Biosca, E. G., Marco-Noales, E. \& Collado, R. (1997). The lipopolysaccharide $O$ side chain of Vibrio vulnificus serogroup $\mathrm{E}$ is a virulence determinant for eels. Infect Immun 65, 2475-2479.

Amaro, C., Lee, C.-T., Wu, K. M., Tsai, S. F. \& Hor, L. I. (2006). Genetic analyses of the plasmids of Vibrio vulnificus biotype 2 serovar E, p.138. Proceedings of the 2nd International FEMS Congress of European Microbiologists, Madrid, Spain.

Arias, C. R., Verdonck, L., Swings, J., Garay, E. \& Aznar, R. (1997). Intraspecific differentiation of Vibrio vulnificus biotypes by amplified fragment length polymorphism and ribotyping. Appl Environ Microbiol 63, 2600-2606.

Arias, C. R., Pujalte, M. J., Garay, E. \& Aznar, R. (1998). Genetic relatedness among environmental, clinical, and diseased-eel Vibrio vulnificus isolates from different geographic regions by ribotyping and randomly amplified polymorphic DNA PCR. Appl Environ Microbiol 64, 3403-3410.

Aznar, R., Ludwig, W. \& Schleifer, K.-H. (1993). Ribotyping and randomly amplified polymorphic DNA analysis of Vibrio vulnificus biotypes. Syst Appl Microbiol 16, 303-309.

Biosca, E. G., Amaro, C., Esteve, C., Alcaide, A. \& Garay, E. (1991). First record of Vibrio vulnificus biotype 2 from diseased European eel, Anguilla anguilla L. J Fish Dis 14, 103-109.

Biosca, E. G., Oliver, J. D. \& Amaro, C. (1996). Phenotypic characterization of Vibrio vulnificus biotype 2; a LPS-based homogeneous O-serogroup within Vibrio vulnificus species. Appl Environ Microbiol 62, 918-927.

Biosca, E. G., Amaro, C., Larsen, J. L. \& Pedersen, K. (1997). Phenotypic and genotypic characterization of Vibrio vulnificus: proposal for the substitution of the subspecific taxon biotype for serovar. Appl Environ Microbiol 63, 1460-1466.

Bisharat, N., Agmon, V., Finkelstein, R., Raz, R., Ben-Dror, G., Lerner, L., Soboh, S., Colodner, R., Cameron, D. N. \& other authors (1999). Clinical, epidemiological, and microbiological features of Vibrio vulnificus biogroup 3 causing outbreaks of wound infection and bacteraemia in Israel. Israel Vibrio Study Group. Lancet 354, 14211424.

Bisharat, N., Amaro, C., Fouz, B., Llorens, A. \& Cohen, D. I. (2007). Serological and molecular characteristics of Vibrio vulnificus biotype 3: evidence for high clonality. Microbiology 153, 847-856.

Clermont, O., Cordevant, C., Bonacorsi, S., Marecat, A., Lange, M. \& Bingen, E. (2001). Automated ribotyping provides rapid phylogenetic subgroup affiliation of clinical extraintestinal pathogenic Escherichia coli strains. J Clin Microbiol 39, 4549-4553.

Dalsgaard, A., Frimodt-Moller, N., Bruun, B., Hoi, L. \& Larsen, J. L. (1996). Clinical manifestations and molecular epidemiology of Vibrio vulnificus infections in Denmark. Eur J Clin Microbiol Infect Dis 15, 227-232.

Dalsgaard, I., Høi, L., Siebeling, R. J. \& Dalsgaard, A. (1999). Indolepositive Vibrio vulnificus isolated from disease outbreaks on a Danish eel-farm. Dis Aquat Organ 35, 187-194.

Esteve, C., Alcaide, E., Herraiz, S., Canals, R., Merino, S. \& Tomás, J. M. (2007). First description of non-motile Vibrio vulnificus strains virulent for eels. FEMS Microbiol Lett 266, 90-97.

Esteve-Gassent, M. D., Fouz, B. \& Amaro, C. (2004). Efficacy of a bivalent vaccine against eel diseases caused by Vibrio vulnificus after its administration by four different routes. Fish Shellfish Immunol 16, 93-105.

Fouz, B. \& Amaro, C. (2003). Isolation of a new serovar of Vibrio vulnificus pathogenic for eels cultured in freshwater farms. Aquaculture 217, 677-682.

Fouz, B., Esteve-Gassent, M. D., Barrera, R., Larsen, J. L., Nielsen, M. E. \& Amaro, C. (2001). Field testing of a vaccine against eel diseases caused by Vibrio vulnificus. Dis Aquat Organ 45, 183-189.

Fouz, B., Alcaide, E., Barrera, R. \& Amaro, C. (2002). Susceptibility of Nile tilapia (Oreochromis niloticus) to vibriosis due to Vibrio vulnificus biotype 2 serovar E. Aquaculture 212, 21-30.

Fouz, B., Larsen, J. L. \& Amaro, C. (2006a). Vibrio vulnificus serovar A: an emerging pathogen in European anguilliculture. J Fish Dis 29, 285-291.

Fouz, B., Zarza, C. \& Amaro, C. (2006b). First description of nonmotile Yersinia ruckeri serovar I strains causing disease in rainbow trout cultured in Spain. J Fish Dis 29, 339-346.

Gardel, C. L. \& Mekalanos, J. J. (1996). Alterations in Vibrio cholerae motility phenotypes correlate with changes in virulence factor expression. Infect Immun 64, 2246-2255.

Gutacker, M., Conza, N., Benagli, C., Pedroli, A., Bernasconi, M. V., Permin, L., Aznar, R. \& Piffaretti, J. C. (2003). Population genetics of Vibrio vulnificus: identification of two divisions and a distinct eelpathogenic clone. Appl Environ Microbiol 69, 3203-3212.

Helms, S. D., Oliver, J. D. \& Travis, J. C. (1984). Role of heme compounds and haptoglobin in Vibrio vulnificus pathogenicity. Infect Immun 45, 345-349.

Hitchcock, P. J. \& Brown, T. M. (1983). Morphological heterogeneity among Salmonella lipopolysaccharide chemotypes in silver-stained polyacrylamide gels. J Bacteriol 154, 269-277.

Høi, L., Dalsgaard, A., Larsen, J. L., Warner, J. M. \& Oliver, J. D. (1997). Comparison of ribotyping and randomly amplified polymorphic DNA PCR for characterization of Vibrio vulnificus. Appl Environ Microbiol 63, 1674-1678. 
Høi, L., Dalsgaard, I., DePaola, A., Siebeling, R. J. \& Dalsgaard, A. (1998). Heterogeneity among isolates of Vibrio vulnificus recovered from eels (Anguilla anguilla) in Denmark. Appl Environ Microbiol 64, 4676-4682.

Laemmli, U. K. (1970). Cleavage of structural proteins during the assembly of the head of bacteriophage T4. Nature 227, 680-685.

Lee, C.-T., Amaro, C., Sanjuán, E. \& Hor, L.-I. (2005). Identification of DNA sequences specific for Vibrio vulnificus biotype 2 strains by suppression subtractive hybridization. Appl Environ Microbiol 71, 5593-5597.

Lewin, A., Bert, B., Dalsgaard, A., Appel, B. \& Høi, L. (2000). A highly homologous $68 \mathrm{kpb}$ plasmid found in Vibrio vulnificus strains virulent for eels. J Basic Microbiol 40, 377-384.

Liu, P. V. (1957). Survey of hemolysin production among species of pseudomonads. J Bacteriol 74, 718-722.

Marco-Noales, E., Milán, M., Fouz, B., Sanjuán, E. \& Amaro, C. (2001). Transmission to eels, portals of entry, and putative reservoirs of Vibrio vulnificus serovar E (biotype 2). Appl Environ Microbiol 67, 4717-4725.

Martin, S. J. \& Siebeling, R. J. (1991). Identification of Vibrio vulnificus $\mathrm{O}$ serovars with antilipopolysaccharide monoclonal antibody. J Clin Microbiol 29, 1684-1688.

Muroga, K., Jo, Y. \& Nishibuchi, M. (1976). Pathogenic Vibrio isolated from cultured eels. I. Characteristics and taxonomic status. Fish Pathol 11, 141-145.

Oliver, J. D. (1989). Vibrio vulnificus. In Food-Borne Bacterial Pathogens, pp. 570-600. Edited by M. P. Doyle. New York: Marcel Dekker.

Pitcher, D. G., Saunders, N. A. \& Owen, R. J. (1989). Rapid extraction of bacterial genomic DNA with guanidinium thiocyanate. Lett Appl Microbiol 8, 151-156.

Reed, M. J. \& Muench, M. (1938). A simple method for estimating fifty percent endpoints. Am J Hyg 27, 493-497.
Sambrook, J., Fritsch, E. F. \& Maniatis, T. (2001). Molecular Cloning: a Laboratory Manual, 2nd edn. Cold Spring Harbour, NY: Cold Spring Harbour Laboratory.

Sanjuán, E. \& Amaro, C. (2004). Protocol for specific isolation of virulent strains of Vibrio vulnificus serovar E (biotype 2) from environmental samples. Appl Environ Microbiol 70, 7024-7032.

Song, Y.-L., Cheng, W., Shen, C.-H., Ou, Y.-C. \& Song, H.-B. (1990). Occurrence of Vibrio vulnificus in cultured shrimp and eel in Taiwan. NSC Symp Ser 16, 172-179.

Sorensen, U. B. \& Larsen, J. L. (1986). Serotyping of Vibrio anguillarum. Appl Environ Microbiol 51, 593-597.

Strom, M. S. \& Paranjpye, R. N. (2000). Epidemiology and pathogenesis of Vibrio vulnificus. Microbes Infect 2, 177-188.

Tison, D. L., Nishibuchi, M., Greenwood, J. D. \& Seidler, R. J. (1982). Vibrio vulnificus biogroup 2: new biogroup pathogenic for eels. Appl Environ Microbiol 44, 640-646.

Towbin, H., Staehelin, T. \& Gordon, T. (1979). Electrophoretic transfer of proteins from polyacrylamide gels to nitrocellulose sheets: procedure and some applications. Proc Natl Acad Sci U S A 76, 4350-4354.

Valiente, E. \& Amaro, C. (2006). A method to diagnose the carrier state of Vibrio vulnificus serovar E in eels: development and field studies. Aquaculture 258, 173-179.

Veenstra, J., Rietra, P. J., Stoutenbeek, C. P., Coster, J. M., de Gier, H. H. \& Dirks-Go, S. (1992). Infection by an indole-negative variant of Vibrio vulnificus transmitted by eels. J Infect Dis 166, 209-210.

Wright, A. C., Miceli, G. A., Landry, W. L., Christy, J. B., Watkins, W. D. \& Morris, J. G., Jr (1993). Rapid identification of Vibrio vulnificus on nonselective media with an alkaline phosphatase oligonucleotide probe. Appl Environ Microbiol 59, 541-546.

Zhou, C., Yang, Y. \& Jong, A. Y. (1990). Mini-prep in ten minutes. Biotechniques 8, 172-173.

Edited by: P. H. Everest 